\title{
Nurses' attitudes towards families in neonatal units*
}

\author{
Atitudes de enfermeiros em relação às famílias em unidades neonatais \\ Actitudes de los enfermeros hacia las familias en las unidades neonatales
}

How to cite this article:

Boyamian TMDL, Mandetta MA, Balieiro MMFG. Nurses' attitudes towards families in neonatal units. Rev Esc Enferm USP. 2021;55:e03684. doi: https://doi. org/10.1590/S1980-220X2019037903684

\section{Thaís Morengue Di Lello} Boyamian ${ }^{1}$

\section{(D) Myriam Aparecida Mandetta ${ }^{2}$ \\ (iD) Maria Magda Ferreira Gomes} Balieiro $^{2}$

* Extracted from the dissertation: "Atitudes dos enfermeiros em relação às famílias de recém-nascidos hospitalizados em unidades neonatais da rede municipal de saúde de São Paulo", Universidade Federal de São Paulo, Escola Paulista de Enfermagem, 2019.

${ }^{1}$ Universidade Federal de São Paulo, Escola Paulista de Enfermagem,

Programa de Pós-Graduação em

Enfermagem, São Paulo, SP, Brazil.

${ }^{2}$ Universidade Federal de São Paulo, Escola Paulista de Enfermagem, Departamento de Enfermagem Pediátrica, São Paulo, SP, Brazil.

\begin{abstract}
Objective: To analyze nurses' attitudes towards families of newborns hospitalized in neonatal units. Method: This is a survey carried out in ten municipal hospitals in São Paulo. Two questionnaires were applied, one from the sociodemographic profile and the other from the characterization of neonatal units, and the Importância das Familias nos Cuidados de Enfermagem - Atitudes dos Enfermeiros scale. Parametric tests ANOVA, Pearson's correlation and Tukey's multiple comparison were applied. Results: The sample consisted of 145 nurses. Most participants had a mean age of 43.7 ( \pm 9.4$)$ years, were female, nursing assistants, have graduated for more than five years and worked at the unit for less than five years. The total score showed a good attitude towards families (77.7), with statistical significance for an 8-hour working day $(p=0.004)$; supervisor position $(\mathrm{p}=0.027)$; participation in short-term courses $(\mathrm{p}=0.029)$; written protocols on family care $(p=0.031)$. Conclusion: Although nurses perceive themselves with positive attitudes towards families, it is necessary to invest in training and changes in structure and organizational processes aimed at including families in neonatal units.
\end{abstract}

DESCRIPTORS

Neonatal Nursing; Infant, Premature; Family; Professional-Family Relations; Intensive Care Units, Neonatal.
Corresponding author:

Thaís Morengue Di Lello Boyamian

Rua Napoleão de Barros, 754, Vila Clementino

CEP 04024-002 - São Paulo, SP, Brazil

thamorengue@hotmail.com
Received: 12/18/2019

Approved: 08/22/2020 


\section{INTRODUCTION}

The birth of a child is a period of transition and transformation for families, especially when it requires admission to a neonatal unit and families are challenged to deal with doubts and uncertainties about the future ${ }^{(1)}$.

The hospitalization of a newborn (NB) is an experience that can generate conflicts in the role of parents, in addition to feelings of vulnerability, characterized by suffering, sadness, fear, concern, frustration, distress, and insecurity ${ }^{(1-2)}$. At this time, families depend on professionals who have patience, effective communication and availability to help and give safety ${ }^{(3-4)}$.

In this regard, the Patient- and Family-Centered Care Model (MCCPF - Modelo de Cuidado Centrado no Paciente e Familia) has been recommended as one of the best practices to include families in neonatal units ${ }^{(5-6)}$. However, this approach is not yet widely adopted by health services, resulting in a gap between the real and the ideal. It is essential to apply care models that consider NBs' and their families' demands and rights ${ }^{(7)}$.

The MCCPF consists of an approach to planning, executing and assessing care that generates benefits for both parties, acknowledging the family as an element of care and a partner in actions and decision-making, through information sharing, respect, dignity, negotiations, participation, collaboration and change of professionals' attitudes when caring for patients and family members ${ }^{(5,8-9)}$.

For this care model to be implemented, it is necessary for nurses to have attitudes that facilitate family participation in caring for their hospitalized members, considering it as a partner and not a supervisory agent ${ }^{(10)}$.

The quality of care and the safety of NBs admitted to a neonatal unit may be related to the work environment and nursing resources; they depend as much on the adequate number of professionals and training as on nurses' interpersonal relationships, behaviors, engagement and attitudes towards families ${ }^{(11-14)}$.

Nurses who have positive attitudes towards families can transmit greater confidence, security and collaborate in developing partnership and improvement in the care process ${ }^{(2)}$.

This research is justified by the fact that although literature $^{(2,15)}$ discusses families' importance in caring for NBs hospitalized in neonatal units, there are studies ${ }^{(6-7)}$ that show limitations for their participation in decision-making and in care; and there are others that reinforce the attitude of health professionals involved in care as decisive for the practice of this care model ${ }^{(10-12)}$. However, this construct has been little explored in studies, especially nurses' attitudes, considering that health professionals are the ones closest to families; and their conduct, engagement and attitudes can contribute to making a difference in the hospitalization experience lived by families in this context.

Thus, this study aimed to analyze nurses' attitudes towards the families of NBs hospitalized in neonatal units.

\section{METHOD}

\section{TYPE OF STUDY}

This is a survey type study carried out in neonatal units of ten hospitals in the municipal health network in the city of São Paulo.

\section{Population}

The population was composed of all nurses working (169) in the neonatal units of the hospitals participating in the research.

\section{SAMPLE DEFINITION}

The sample calculation was based on a $5 \%$ margin of error and a 95\% confidence level and associated with a $84.7 \%$ response rate, obtained in a previous study on nurses' attitudes towards families in Brazil ${ }^{(16)}$. Thus, the minimum sample defined was 92 nurses.

Inclusion criteria: Hired or back-up nursing assistants and supervisors from neonatal units of the municipal health network in the city of São Paulo were included. Exclusion criteria: Nurses on vacation or absent during data collection for any reason were excluded.

\section{DATA COlleCtion}

Data collection was carried out from December 20, 2017 to July 10, 2018. Two questionnaires were used, one to obtain information about the characteristics of neonatal units, answered by nursing supervisors, and another related to nurses' sociodemographic characteristics. To measure nurses' attitudes, the Importância das Famílias nos Cuidados de Enfermagem - Atitudes dos Enfermeiros (IFCE-AE) scale was used. This scale underwent semantic equivalence in $\mathrm{Brazil}^{(16)}$ based on the culturally adapted and validated version in Portugal of the Families' Importance in Nursing Care Nurses' Attitudes (FINC-NA) ${ }^{(17)}$ scale, aiming at measuring nurses' attitudes about the importance of involving families in nursing care.

Using the IFCE-AE scale was authorized in writing by the Brazilian authors who made the semantic equivalence for Brazilian Portuguese.

The IFCE-AE scale has three dimensions defined as: "Family: responsive partner and coping resources", consisting of 12 questions and a score ranging from 12 to 48; "Family: resources in nursing care", consisting of 10 questions and score ranging from 10 to 40; "Family: burden", composed of four questions and score ranging from 4 to $16^{(16-17)}$.

Each question contains four answer options on a Likerttype scale, which varies between totally disagree (1), disagree (2), agree (3), and totally agree (4). The total score ranges from 26 to $104^{(16-17)}$.

The data collection instruments were made available to the participants digitally through the Red Cap ${ }^{\circledR}$ program, whose link was sent by email or WhatsApp ${ }^{\oplus}$ so that they could respond at the most opportune moment. In some cases, the instruments were delivered in print and the answers were typed by the researcher in Red Cap. 


\section{DATA ANALYSIS AND TREATMENT}

The interpretation of the score obtained on the IFCE-AE scale considers that the higher the total score, the more supportive attitudes are presented by nurses to families. For this calculation, it is recommended to invert dimension 3's responses $^{(17-18)}$.

In an analysis of each dimension carried out separately, dimension 3 was not inverted, because the higher the score in the first two dimensions of the scale and the lower score in the last dimension, the greater nurses' supportive attitude towards families ${ }^{(16)}$.

Analysis of nurses' attitudes was calculated using quartiles (represented by "q"). In dimensions 1 (Family: responsive partner and coping resources), 2 (Family: resources in nursing care), and total scale, scores below the first quartile were considered as low support attitudes towards families. Between the first and third quartiles, the attitude was considered good, and above the third quartile, excellent ${ }^{(16,18)}$.

In dimension 3 (Family: burden), interpretation was made considering scores below the first quartile as excellent, between the first and third quartiles, as good, and above the third quartile, low support attitudes towards families.

Descriptive and inferential analyzes were performed using Statistical Package for the Social Sciences ${ }^{\oplus}$ (SPSS), version 20, Minitab ${ }^{\circledR} 16$ and Excel Office ${ }^{\varpi}$ 2016. Parametric tests were used, as it was concluded, through the Kolmogorov-Smirnov (KS) test, that there was normality between variables. The ANOVA test was used to compare the scale scores with qualitative variables; Pearson's Correlation was used to measure the correlation of the IFCE-AE scale with ordinal quantitative or qualitative variables; Tukey's Multiple Comparison (post-hoc) was used to compare all levels with pairs referring to working hours and existence of written routines and protocols with description of family care. Cronbach's Alpha was adopted to verify the scale's internal consistency.

\section{ETHICAL ASPECTS}

This study was approved by the Research Ethics Committee of the proposing institution, under Opinion 2.263.987 of September 7, 2017 and Opinion 2.632.320 of May 3, 2018. It respected Resolution 466/12, of the Brazilian National Health Council on research with human beings.

The Informed Consent Form was used in the online format, stored in Red Cap ${ }^{\oplus}$ and sent by email to all participants, guaranteeing their voluntary participation, confidentiality, anonymity, and the possibility of withdrawing from the study at any time. To all participants who answered the questions on the printed instrument, the consent form was signed in two copies, one of which remained with the researcher.

Each hospital was identified by a letter (A-J), and these letters were unrelated to hospital names or data collection sequence.

\section{RESULTS}

The sample consisted of 145 nurses, accounting for $85.8 \%$ of the study population. Most, 139 (96.0\%), were female, $130(89.6 \%)$ with an assistance position, and the mean age was 43.7 years $( \pm 9.4)$. Concerning professional training and work time in neonatology, 126 (86.9\%) participants had over five years and 81 (55.8\%) had worked for less than five years, respectively. As for qualification, 119 (82.1\%) specialized in different fields. Considering the total sample, 66 (45.5\%) nurses specialized in pediatric and/or neonatal fields.

When analyzing the profile of the 12 (8.2\% of the total sample) nursing supervisors separately, a mean age of 46.6 years $( \pm 9.3)$ was evidenced; $11(91.6 \%)$ were female; 10 (83.3\%) had more than 15 years of training as a nurse and more than five years of experience in neonatology. Among these nurses, $10(83.3 \%)$ were specialists, six $(50 \%$ of total supervisors) in pediatric and/or neonatal fields.

The administration of the participating hospitals showed a difference in relation to their types: municipal health authority, direct administration of the Municipal Health Department, and social health organization. There was also variation in the number of beds in neonatal units from 10 to 60 . As for care processes, $70 \%$ of the units presented written routines and protocols, $20 \%$ with description of family care. Neonatal units did not have a program to prepare parents for hospital discharge, with guidance provided verbally in $80 \%$ of hospitals. Training employees regarding MCCPF was not identified in any hospital.

Parents' permanence together with their NBs, for 24 hours a day, occurred in $50 \%$ of neonatal units, and, in the others, there was a need for relay between them. As for participation of parents in care, $70 \%$ of the units allowed hygiene and food care provision under the supervision of nursing. As well as witnessing the execution of low complexity procedures by the health team. However, in $20 \%$ of the units the presence of parents was allowed during highly complex procedures. In relation to cardiopulmonary resuscitation (CPR), only one unit (10\%) reported permanence of parents (if desired by them) through external glass.

The visitation policy is authorized for grandparents and siblings, restrictedly. Other extended family or family relation members are not included. However, negotiation is possible in some units.

With regard to social support for parents, it was found that $40 \%$ had chaplaincy services and that all units allowed religious visits; $40 \%$ offered parent group meetings, but only one with the presence of nursing supervisors; $30 \%$ had a volunteer service.

Most hospitals (70\%) provided private space for families to feel comfortable inside or outside neonatal units. However, of these, $40 \%$ were destined exclusively to mothers. Within the units, the most frequent type of accommodation was a simple chair, insufficient for the number of beds. Only one hospital had a recliner beside each bed for mother or father to remain.

The IFCE-AE showed good internal consistency, with a 0.87 Cronbach's alpha.

By analyzing nurses' attitudes (Table 1), it was found that the mean of the IFCE-AE's total score was 77.7, showing a good attitude towards families. In dimension 1 (Family: responsive partner and coping resources), the mean was 35.3; in dimension 2 (Family: resources in nursing care), the mean 
was 30.9; in dimension 3 (Family: burden), the mean was 8.5 , showing supportive attitudes.

Table 1 - Mean of the total score and of each IFCE-AE dimension - São Paulo, SP, Brazil, 2019.

\begin{tabular}{|c|c|c|c|c|c|c|}
\hline $\begin{array}{l}\text { IFCE-AE scale } \\
\text { scores }\end{array}$ & Mean & $\begin{array}{l}\text { Standard } \\
\text { deviation }\end{array}$ & $q^{*} 1$ & $q^{* 3}$ & Min & Max \\
\hline $\begin{array}{l}\text { Dimension } \\
1 \text { - Family: } \\
\text { responsive } \\
\text { partner } \\
\text { and coping } \\
\text { resources }\end{array}$ & 35.3 & 5.7 & 32 & 39 & 15 & 48 \\
\hline $\begin{array}{l}\text { Dimension } \\
2 \text { - Family: } \\
\text { resources in } \\
\text { nursing care }\end{array}$ & 30.9 & 4.6 & 28 & 34 & 20 & 40 \\
\hline $\begin{array}{l}\text { Dimension } \\
3 \text { - Family: } \\
\text { burden }\end{array}$ & 8.5 & 2 & 7 & 10 & 4 & 13 \\
\hline Total score ${ }^{a}$ & 77.7 & 10.8 & 70 & 86 & 45 & 104 \\
\hline
\end{tabular}

Note: ${ }^{*} q$-Quartile; ** a - For this calculation, the score for the questions in dimension 3 - Family: burden was analyzed inverted. $n=145$.

Although neonatal units had different characteristics in terms of structure and care processes, in the association of the attitude scores mean in each dimension and in the total scale by hospital, there was no statistically significant difference.

Nursing supervisors had higher scores of positive attitudes towards families in dimensions 1 (Family: responsive partner and coping resources) $(\mathrm{p}=0.031), 2$ (Family: resources in nursing care) $(\mathrm{p}=0.037)$ and total scale $(\mathrm{p}=0.030)$. However, in dimension 3 (Family: burden) $(\mathrm{p}=0.484)$, there was no statistically significant difference.

The highest scores of positive attitudes were evidenced in dimensions 1 and 2 in relation to nurses with an eight-hour workday, corresponding to nursing supervisors.

In the association of neonatal units' characteristics with the scale, there was a statistically significant difference in dimension $1(\mathrm{p}=0.031)$ regarding the existence of protocols and care routines with description of family care.

When associating the IFCE-AE scores with type of training performed by nurses during data collection, it was found that those who took short-term courses had higher scores of positive attitudes in dimension $1(p=0.020)$ and in the total score $(\mathrm{p}=0.029)$. It should be noted that short-term courses were not exclusively in neonatology.

As for nurses' answers to the questions on the IFCE-AE scale, in dimension 1 , the highest frequency of responses was in agreement, especially for questions 14: I invite family members to discuss after care; 16 : I ask family members how I can help; and 25: I consider myself as a resource for families, so they can better deal with the situation.

In contrast to this dimension, in question 24: I invite family members to give their opinion on care planning, the highest frequency of responses was disagreement.

In dimension 2, most nurses answered "I completely agree" and "I agree" for the questions on scale 1: It is important to know who the family members are; 3: A good relationship between family members gives me work satisfaction; 5 : The presence of family members is important for me as a nurse; 21: I gain valuable knowledge with families that I can put into practice at work; 22: It is important to devote time to families. However, they answered "I disagree" to question 10: The presence of family members relieves my workload.

In dimension 3 , there was a prevalence of disagreement responses to questions 2: The presence of family members makes my job more difficult; 8: I don't have time to care for families; and 26: The presence of family members makes me feel stressed. In the same dimension, in question 23: The presence of family members makes me feel I am being judged, the highest response rate was agreement.

\section{DISCUSSION}

The results indicated that nurses consider themselves as having good attitudes towards families of NBs hospitalized in neonatal units. The score's general mean ranged from 75 to 86 , similar to the findings of studies conducted in Europe ${ }^{(19-20)}$ and in Brazil $^{(16,21)}$.

However, the analysis carried out in relation to all answers given to the scale's questions pointed out that nurses feel they are being judged by families, disagree with the need to invite family members to participate in care planning and believe that the presence of family members increases their workload. Although these responses are negative attitudes of approaching families, this did not influence the overall score, identified as a good attitude.

This finding deserves further investigation because, as recommended by the authors of a study ${ }^{(20)}$ carried out in Portugal with hospital nurses and which used the IFCE-AE, it is necessary to combine other data collection methods on this construct to favor the understanding of the daily life of professional practice, considering the existence of a dichotomy between nurses' thinking and acting.

Despite nurses' positive attitudes expressed by the IFCE-AE scale, the authors of a study carried out in a Swiss university hospital ${ }^{(22)}$ observed that, during focus group sessions, there were reports of challenges for the daily work with families in a neonatal unit. These challenges, limiting or facilitating, are related to units' culture, organizational policy, structure, care processes, adequate number of professionals and their level of training. They identified that the greater the limiting challenges, the more frequent the friction and the less the actions in favor of families.

The results showed that structure and care processes' characteristics of the participating hospitals are restrictive to the presence and participation of families, being a factor that can interfere with the MCCPF adoption. The reality observed in neonatal units, as an exclusive resting place for mothers in four hospitals and accommodation within the units in chairs, does not comply with the Child and Adolescent Statute (ECA - Estatuto da Criança e do Adolescente), which states that "health care establishments, including neonatal, intensive care and intermediate care units, must provide conditions for a parent or guardian to stay in the hospital full time, in cases of hospitalization of a child or adolescent"(23). The structural conditions presented in the participating hospitals make it difficult for parents to stay in the units. 
The Ministry of Health in Brazil, through the Brazilian National Humanization Policy (Politica Nacional de Imunização) - Humaniza SUS and the Humanized Care for low birth weight NBs - Kangaroo Method, aims to improve care with the participation of families in health care contexts ${ }^{(24-25)}$. In the present study, this participation of families provided for in the program is hindered by the institutional routines that restrict the visit of extended families, not allowing parents to remain together within neonatal units when accompanying their children.

Moreover, parents' participation in NB care and the presence in low and high complexity procedures are restrictive, which can interfere with the bond construction and in the parents' learning process in caring for their children. Even so, it is necessary to consider not only the presence of families, but rather, a partnership relationship with inclusion in care, negotiations, and decision-making ${ }^{(26)}$; therefore, these actions must be incorporated into practice.

Nursing supervisors had higher scores of positive attitudes towards families, differing from most nursing assistants. It is believed that supervisors' experience, professional maturity and professional training can help understand the importance of families in caring for hospitalized NB. A study ${ }^{(27)}$ carried out in Japan on nursing supervisors' managerial competency pointed out that learning built with work experience contributes to acquiring more managerial competences by the supervisor. Such competencies are related to leadership capacity, goal attainment, communication and education, which could favor contact with families and contribute to the best scores of attitudes ${ }^{(27-28)}$.

In this study, most nurses in the units did not specialize in pediatric and/or neonatal fields, and this is a fact that should be discussed, reviewed and analyzed by the institutions, since professional expertise and certification in the specialty of practice contribute with better results and fewer complications for patients, with an impact on families and society ${ }^{(29)}$.

The training provided by nurses was related to humanization of care, the Kangaroo Method and the Baby-Friendly Hospital Initiative. However, they did not contemplate the central elements for a practice with families, as recommended by the MCCPF. It is believed that being unaware of how to care for families can interfere with nurses' attitudes, coinciding with the results of a Swedish study ${ }^{(18)}$ with the application of the scale in the original version (FINC-NA), in which the nurse with the lowest score of support attitudes to families was the one who had not participated in any type of educational program with an approach to family.

It was evident, in the present study, that the existence of written assistance routines, with a description of care for families, showed a significant association with nurses' attitudes, demonstrating the positive influence of organizational culture, translated into institutional routines and protocols on professionals' attitudes.

A study ${ }^{(30)}$ carried out with parents of NBs admitted to a Neonatal Intensive Care Unit in Paraná State pointed out that the existence of a written protocol for welcoming parents to the institution directly reflects on positive results and increases the quality of care provided. However, it is necessary to investigate this aspect more widely, because perhaps nurses' attitudes in the present study were positive in hospitals where written routines and protocols are already established and not because they believe in the benefits of working in partnership with families.

Protocols can be important to direct care, but flexibility is necessary when thinking that each patient and their family should be treated according to individual needs. Thus, more important than protocols are nurses' awareness and change of attitudes, when understanding families' importance in patient care.

The results revealed in this research demonstrate weaknesses in structure and process in the units surveyed and the need to create an education program for nurses about care with families. Based on this knowledge, care programs for families, protocols and care routines that contemplate the MMCPF assumption can be developed, in addition to professional training, always aiming to improve care processes for NBs and their families.

The study's limitation was the fact that it identified nurses' perceptions of their attitudes towards families in neonatal units, an aspect that can be extended in other investigations to explain professionals' actions in their daily practice with families.

\section{CONCLUSION}

This study identified that nurses' perception was of a good attitude towards families with statistical significance for an 8-hour working day, supervisor position; participation in short-term courses; existence of written protocols on family care. However, nurses showed that they perceive themselves to be assessed by families, consider that their workload increases with the presence of families and disagree with the importance of inviting them to care planning.

Professionals' change in attitude, behavior and perception about families' involvement in NB care may be the first step towards the MCCPF adoption as a reference to guide professionals' actions. Training nursing assistants in neonatal units on this model of care is necessary and can improve relationships, in addition to providing opportunities for growth and empowerment of families for safe care of NBs after hospital discharge.

\section{RESUMO}

Objetivo: Analisar as atitudes dos enfermeiros em relação às famílias de recém-nascidos hospitalizados em unidades neonatais. Método: Survey realizado em dez hospitais municipais de São Paulo. Aplicaram-se dois questionários, um do perfil sociodemográfico e outro da caracterização das unidades neonatais, e a escala Importância das Famílias nos Cuidados de Enfermagem - Atitudes dos Enfermeiros. Os testes paramétricos ANOVA, a Correlação de Pearson e a Comparação múltipla de Tukey foram aplicados. Resultados: A amostra foi composta por 145 enfermeiros. A maioria dos participantes tinha média de idade de 43,7 $( \pm 9,4)$ anos, do sexo feminino, em função assistencial, com tempo de formado há mais de cinco anos e de atuação na unidade há menos de cinco anos. O escore total indicou boa atitude em relação às famílias $(77,7)$, com significância estatística para jornada de trabalho de 8 horas ( $\mathrm{p}=0,004)$, cargo de supervisor 
( $p=0,027)$, participação em cursos de curta duração $(p=0,029)$; e protocolos escritos sobre cuidados à família ( $p=0,031)$. Conclusão: Apesar de os enfermeiros perceberem-se com atitudes positivas em relação às famílias, deve-se investir em capacitação e em mudanças na estrutura e nos processos organizacionais, visando à inclusão da família nas unidades neonatais.

\section{DESCRITORES}

Enfermagem Neonatal; Recém-Nascido Prematuro; Família; Relações Profissional-Família; Unidades de Terapia Intensiva Neonatal.

\section{RESUMEN}

Objetivo: Analizar las actitudes de los enfermeros hacia las familias de los recién nacidos hospitalizados en unidades neonatales. Método: Una survey realizada en diez hospitales municipales de São Paulo. Se aplicaron dos cuestionarios, uno del perfil sociodemográfico y otro de la caracterización de unidades neonatales, y la escala Importância das Famílias nos Cuidados de Enfermagem-Atitudes dos Enfermeiros. Se aplicaron pruebas paramétricas ANOVA, correlación de Pearson y comparación múltiple de Tukey. Resultados: La muestra estuvo conformada por 145 enfermeros. La mayoría de los participantes tenía una edad promedio de 43,7 $( \pm 9,4)$ años, mujeres, en asistencia, con tiempo desde la graduación por más de cinco años y trabajando en la unidad por menos de cinco años. La puntuación total indicó buena actitud hacia las familias $(77,7)$, con significancia estadística para jornada laboral de 8 horas ( $p=0,004)$, puesto de supervisor $(p=0,027)$, participación en cursos cortos $(p=0,029)$; $y$ protocolos escritos sobre cuidados familiares $(p=0,031)$. Conclusión: Si bien los enfermeros se perciben con actitudes positivas hacia las familias, se debe invertir en capacitación y cambios en la estructura y procesos organizativos, con el objetivo de incluir a la familia en las unidades neonatales.

\section{DESCRIPTORES}

Enfermería Neonatal; Recién Nacido Prematuro; Familia; Relaciones Profesional-Familia; Unidades de Cuidado Intensivo Neonatal.

\section{REFERENCES}

1. Almeida CR, Morais AC, Lima KDF, Silva ACOC. Cotidiano de mães acompanhantes na Unidade de Terapia Intensiva Neonatal. Rev Enferm UFPE. [Internet]. 2018 [citado 2019 fev. 10];1(7):1949-56. Disponível em: https://periodicos.ufpe.br/revistas/revistaenfermagem/ article/

2. Gomes GC, Xavier DM, Pintanel AC, Farias DHR, Lunardi VL, Aquino DR. Meanings attributed by family members in pediatrics regarding their interactions with nursing professionals. Rev Esc Enferm USP. 2015;49(6):953-9. doi: 10.1590/S0080-623420150000600011

3. Balbino FS, Meschini GFG, Balieiro MMFG, Mandetta MA. Percepção do cuidado centrado na família em unidade neonatal. Rev Enferm UFSM. 2016;6(1):84-92. doi: 10.5902/2179769216340

4. Cabeça LPF, Sousa FGM. Dimensions qualifying for communication of difficult news in neonatal intensive care unit. Rev Online de Pesq Cuid Fundam [Internet]. 2017 [cited 2017 Apr 27];9(1):37-50. Available from: seer.unirio.br/index.php/cuidadofundamental/article/ view/4153

5. Skene C, Gerrish K, Price F, Pilling E, Bayliss P. Developing family- centred care in a Neonatal Intensive Care Unit: an action research study protocol. J Adv Nurs. 2015;72(3):658-68. doi: 10.1111/jan.12863

6. Craig JW, Glick C, Philips R, Hall SL, Smith J, Browne J. Recommendations for involving the family in developmental care of the NICU baby. J Perinatol. 2015;35 Suppl 1:S5-8. doi: 10.1038/jp.2015.142

7. Hernández NL, Rubio Grillo MH, Lovera A. Strategies for neonatal developmental care and family-centered neonatal care. Invest Educ Enferm. 2016;34(1):104-12. doi: 10.17533/udea.iee.v34n1a12

8. Johnson BH. Promoting patient-and family-centered care through personal stories. Acad Med. 2016;91(31):297-300. doi: 10.1097/ ACM.0000000000001086

9. Institute for Patient and Family Centered-Care. Transforming health care through partnerships [Internet]. Bethesda; 2016 [cited 2016 July 01] Available from: www.ipfcc.org/

10. Corrêa AR, Andrade AC, Manzo BF, Couto DL, Duarte ED. The family-centered care practices in newborn unit nursing perspective. Esc Anna Nery. 2015;19(4):629-34.

11. Montes Bueno MT, Quiroga A, Rodríguez S, Sola A. Acceso de lãs famílias a las unidades de internacion de Neonatologia en Iberoamérica: uma realidad a mejorar. An Pediatria (Barc). 2016;85(2):95-101. doi: 10.1016/j.anpedi.2015.07.030

12. Sloane DM, Smith HL, McHugh MD, Aiken LH. Effect of changes in hospital nursing resources on improvements in patient safety and quality of care a panel study. Med Care. 2018;56(12):1001-8. doi: 10.1097/MLR.0000000000001002

13. Aiken LH, Sloane MD, Ball J, Bruyneel L, Rafferty AM, Griffiths P. Patient satisfaction with hospital care and nurses in England: an observational study. BMJ Open. 2018;8:e019189. doi: 10.1136/bmjopen-2017-019189

14. Carthon JMB, Hatfield L, Plover C, Dierkes A, Davis L, Hedgeland T, et al. Association of nurse engagement and nurse staffing on patient safety. J Nurs Care Qual. 2019;34(1):40-6. doi: 10.1097/NCQ. 0000000000000334

15. Raiskila S, Lehtonen L, Silnes Tandberg B, Normann E, Ewald U, Caballero S, et al. Parent and nurse perceptions on the quality of familycentred care in11 European NICUs. Austr Crit Care. 2016;29(4):201-9. doi: 10.1016/j.aucc.2016.09.003

16. Ângelo M, Cruz AC, Mekitarian FFP, Santos CCS, Martinho MJCM, Martins MMFPS. Nurses' attitudes regarding the importance of families in pediatric nursing care. Rev Esc Enferm USP. 2014;48(spe n.):75-81. doi: 10.1590/S0080-623420140000600011

17. Oliveira PCM, Fernandes HIV, Vilar AISP, Figueiredo MHJS, Ferreira MMSRS, Martinho MJCM, et al. Attitudes of nurses towards families: validation of the scale Families' Importance in Nursing Care-Nurses Attitudes. Rev Esc Enferm USP. 2011;45(6):1331-7. doi: 10.1590/ s0080-62342011000600008.

18. Benzein E, Johansson P, Arestedt KF, Saverman BI. Nurses' atittudes about the importance of families in nursing care: a survey of Swedish nurses. J Fam Nurs. 2008;14(2):162-80. doi: 10.1177/1074840708317058 
19. Fernandes CSNN, Nóbrega MPSS, Angelo M, Torre MI, Chaves SCS. Importância das famílias nos cuidados à pessoa com transtorno mental: atitudes de enfermeiros. Esc Anna Nery. 2018;22(4):e20180205. https://doi.org/10.1590/2177-9465-ean-2018-0205

20. Fernandes CS, Gomes JAP, Martins MM, Gomes BP, Gonçalves LHT. A importância das famílias nos cuidados de enfermagem: atitudes dos enfermeiros em meio hospitalar. Rev Enf Ref. 2015; serie IV(7):21-30. http://dx.doi.org/10.12707/RIV15007

21. Ribeiro JSST, Sousa FGM, Santos GFL. Atitudes de enfermeiros nos cuidados com famílias no contexto do parto e puerpério imediato. Rev Online Pesq Fundam. 2018;10(3):784-92.

22. Naef R, Kläusler-Troxler M, Ernst J, Huber S, Dinten-Schmid B, Karen T, et al. Translating family systems care into neonatology practice: a mixed method study of practitioners' attitudes, practice skills and implementation experience. Int J Nurs Stud. 2019;102:103448. doi: 10.1016/j.ijnurstu.2019.103448

23. Brasil. Lei n. 8.069, de 13 de julho de 1990. Dispõe sobre o Estatuto da Criança e do Adolescente e dá outras providências [Internet]. Brasília; 1990 [citado 2017 abr. 27]. Disponível em: http://www.planalto.gov.br/ccivil_03/leis/l8069.htm

24. Brasil. Ministério da Saúde. Política Nacional de Humanização (PNH). Brasília; 2013

25. Brasil. Ministério da Saúde. Atenção Humanizada ao Recém-Nascido de Baixo Peso. Método Canguru: manual técnico [Internet] Brasília; 2011 [citado 2018 dez. 04] Disponível em: http://bvsms.saude.gov.br/bvs/publicacoes/atencao_humanizada_recem_nascido_canguru.pdf

26. Uniacke S, Browne TK, Shields L. How should we understand family-centred care? J Child Health Care. 2018;22(3):460-9. doi: $10.1177 / 1367493517753083$

27. Kuraoka Y. The relationship between experiential learning and nursing management competency. J Nurs Adm. 2019;49 (2):99-104. doi: 10.1097/NNA.0000000000000717

28. Muller LA, Lima SBS, Eberhardt TD, Fonseca GGP, Rabelo SK, Fonseca DF. Percepção de enfermeiros sobre o processo de gestão em um hospital universitário. Rev Enferm UFPE [Internet]. 2017 [citado 2019 abr. 15];11 Supl.12:5321-7. Disponível em: https://periodicos.ufpe. $\mathrm{br} /$ revistas/revistaenfermagem/article/view/231332

29. Hickey PA, Gauvreau K, Porter C, Connor JA. The impact of critical care nursing certification on pediatric patient outcomes. Pediatr Crit Care Med. 2018;19(8):718-24. doi: 10.1097/PCC.0000000000001609

30. Soares LG, Soares LG, Decesaro MN, Higarasho IH. Perception of families on reception in the neonatal context during an intervention process. Rev Online Pesq Cuid Fundam [Internet]. 2019 [cited 2019 Apr 27];11(1):147-53. Available from: http://www.seer.unirio.br/ index.php/cuidadofundamental/article/view/6577

Financial support:

Coordenação de Aperfeiçoamento de Pessoal de Nível Superior (CAPES), master's Scholarship. 